\title{
CALCULATION OF FITS FOR CYLINDRICAL CONNECTIONS WITH KEY FOR REDUCERS IN AGRICULTURAL MACHINERY
}

\author{
Mikhail Erohin, Oleg Leonov, Uriy Kataev, Ulia Vergazova \\ Russian Timiryazev State Agrarian University, Russia \\ smdm@rgau-msha.ru, oaleonov@rgau-msha.ru,ykataev@rgau-msha.ru,vergazova@rgau-msha.ru
}

\begin{abstract}
The lack of reliability of cylindrical connections with the key is explained not only by the low quality of the materials of the parts, but also by the inconsistency of the fit. The presence of a gap in these compounds leads to fretting and fretting corrosion due to the ingress of wear products, dust, moisture and soil. Increasing the gap leads to beatings and plastic deformations of surfaces. A method for calculating the fits with interference has been developed for cylindrical connections with a key. The method includes calculation of the pressure from the cantilever and radial forces in order to exclude the opening of the joint at low interference values and the transition to the zone of plastic deformation due to exceeding the maximum pressure at high interference. To ensure possible disassembly and assembly of the connection in the field the operational requirements for limiting the maximum interference were calculated to replace the drive elements, such as chains, sprockets, pulleys, belts, etc. Restrictions on the roughness of the hole and the shaft were introduced to ensure the quality of the contact area in the fit. Geometric parameters of keyways are introduced into calculations. The recommendations for thermal calculation of the dimensions of parts in the landing were improved. The dynamic coefficient, which takes into account the possible overload of connections, is included in the calculation of the minimum interference. As a result of testing the methodology, it was revealed that, when applying the obtained landings, the wear rate of the connection is significantly reduced. As an example of cylindrical connections with the key of reducers "Mosselmash", the wear rate of the sprocket-shaft connection with the use of the fit $30 \mathrm{H} 7 / \mathrm{x} 6 \mathrm{decreased}$ by 12 times and the wear rate of the connection gear in the fit 40H9/z8 decreased by 3 times.
\end{abstract}

Keywords: connection, fit, clearance, interference, surface roughness.

\section{Introduction}

In the concept of modernization of the engineering and technical system of agriculture in Russia before 2020 the necessity of increasing of the reliability factor is established [1]. Therefore, the crucial task is to increase the production reliability of gear and transmission systems, which are used in AIC [2;3]. In seasonal farm works failure and off period of machinery are associated with economical loss, but increasing its service life with appreciable economical effect [4]. Machinery repair and quality control multiple purposes are solved by using new methods and technologies [5]. Under the repair it is important to take in account the changes in the unified system of tolerances and fits [6].

For all and specific purposes in agricultural machinery the reducer, belt drive and chain belt are widely used during transfer and at the moment of transfer. In such drives, the cylindrical connections with key are usually applied [7], but its reliability fails to satisfy the current requirements [8].

The lack of reliability of such compounds is due not only to the quality of the materials of the parts, but also to the mismatch of landings and interchangeability norms.Interchangeability in the technical literature is considered as a property of structural elements made with a certain accuracy of geometric, mechanical, electrical and other parameters, in order to provide the desired performance, regardless of the time and place of manufacture during assembly, repair and replacement of these elements.

The analysis of technical documentation shows that $60 \%$ connections have clearance fits, $40 \%$ transition fits, and interference fits practically did not exist.

The presence of a gap in such compounds leads to fretting, micro-breaks, formation of wear particles and an increase in the wear rate. In addition, dust, moisture and soil particles get into the gap in the open joints. An increasing of clearance provides beating, crushing of surfaces and plastic deformation.

Thus, to transmit torque in connections with a key, it is necessary to use a fit of interference, taking into account the radial and cantilever loads that have these connections in agricultural machines. To ensure the possibility of disassembling and assembling the connection in field conditions, it is necessary to calculate the maximum tension not from the strength condition, but from the condition of disassembly of the connection by the puller. These activities will significantly increase the durability of the connection with the key. 


\section{Results and discussion}

The method of calculation of landings with tension is successfully used and improved for various connections, there is a refinement of each of the influencing parameters $[9,10]$.

Standard methodology for calculation of interference for such connections is unacceptable. It does not take into account such performance factors:

1. presence of cantilever and radial forces from which the joint can be opened;

2. necessity of disassembly and assembly of such connections under field conditions by the way of replacing drives, such as chains,sprockets, belts;

3. range of annual fluctuations of temperature that may lead to the disclosure of the joint or exceeding the permissible pressure.

It is also necessary to limit the surface roughness of the connected parts to ensure a high-quality contact area in order to reduce the effort during disassembly.

Taking into account these properties a methodology was created of calculation of the maximum and minimum interference for cylindrical joints with a key, Table 1.

\section{Main differences in methodology of calculation of fits with interference and proposed procedure for connections with key}

\begin{tabular}{|l|l|l|}
\hline \multirow{2}{*}{ Calculation step } & \multicolumn{2}{|c|}{ Methodology elements } \\
\cline { 2 - 3 } $\begin{array}{l}\text { Calculation of } \\
\text { minimal pressure } p_{\text {min }}\end{array}$ & $\begin{array}{l}\text { When action torque } M_{\mathrm{KP}} \\
\text { and axial force } P_{\mathrm{OC}}\end{array}$ & $\begin{array}{l}\text { pombined action of torque } M_{\mathrm{KP}} \text {, axial } \\
\text { force } P_{\mathrm{OC}}, \text { radial force } P_{\mathrm{r}} \text { and cantilever load } \\
P_{\mathrm{K}}, \text { according with key width }\end{array}$ \\
\hline $\begin{array}{l}\text { Calculation of } \\
\text { maximum pressure } \\
p_{\max }\end{array}$ & $\begin{array}{l}\text { When failure of fluidity } \\
\text { of weak material in } \\
\text { play } M_{\mathrm{KP}} \text { and } P_{\mathrm{OC}}\end{array}$ & $\begin{array}{l}\text { When failure of weak material according to } \\
\text { summary pressure of radial force and } \\
\text { cantilever load } p_{\min (\mathrm{r})} \text {, according to key width }\end{array}$ \\
\hline $\begin{array}{l}\text { Calculation of } \\
\text { maximum } \\
\text { interference } N_{\mathrm{Pmax}}\end{array}$ & $\begin{array}{l}\text { When plastic flow is } \\
\text { lacking }\end{array}$ & $\begin{array}{l}\text { When plastic flow is lacking and calculating } \\
\text { of interference, which provides fast } \\
\text { dismount ability of connection }\end{array}$ \\
\hline $\begin{array}{l}\text { Correcting of } \\
\text { interference limit }\end{array}$ & $\begin{array}{l}\text { Dimension of crushed } \\
\text { roughness of any type. } \\
\text { Corrected on heat } \\
\text { expansion }\end{array}$ & $\begin{array}{l}\text { With limitation of crushed roughness shaft } \\
\text { and hole } \\
\text { With analysis of heat expansion - pressure } \\
\text { of elements }\end{array}$ \\
\hline
\end{tabular}

In such case, pressure occurred for force compensation and rotation moments that function along the surfaces of friction taking into account the geometrical parameters of key in the formula

$$
p_{\min (l)}=\sqrt{\left(\frac{2 \cdot T}{\left(\pi \cdot d_{n}-b\right) \cdot d_{n} \cdot l \cdot f}\right)^{2}+\left(\frac{P_{a}}{\left(\pi \cdot d_{n}-b\right) \cdot l \cdot f}\right)^{2}},
$$

where $f$-friction coefficient;

$l$ - connectionlength, $\mathrm{m}$;

$d_{n}$ - connection diameter, $\mathrm{m}$;

$b$ - key width, m;

$T$ - torque acting on the connection, $\mathrm{N} \cdot \mathrm{m}$;

$P_{a}-$ axial force, $\mathrm{N}$.

For cylindrical connection with key usually the radial force $P_{r}$ and cantilever load $P_{k}$ effect. Minimum pressure $p_{\min (r)}$ on thecontact areas that is necessary for opening joint exception between interfacing surfaces is calculated by the formula

$$
p_{\min (r)}=\vec{p}_{\min \left(P_{r}\right)}+\vec{p}_{\min \left(P_{c}\right)},
$$

where $p_{\min (P \mathrm{r})}$ - pressure for exception of opening joint from radial load $P_{\mathrm{r}}$;

$p_{\min (P \mathrm{c})}$ - pressure for exception of opening joint from cantileverload $P_{\mathrm{c}}$. 
In order to ensure durability these parameters of pressure it is recommended to calculate linearly. For cylindrical connections, taking into account the key geometry, we will get such pressure forms, acting radially (denote in general terms $\left.-p_{\min (r)}\right)$ :

$$
\begin{aligned}
& p_{\min \left(P_{r}\right)}=\frac{P_{r}}{\left(d_{n}-b\right) \cdot l} ; \\
& p_{\min \left(P_{c}\right)}=\frac{3 \cdot P_{c} \cdot L}{\left(d_{n}-b\right) \cdot l^{2}} .
\end{aligned}
$$

where $L-$ shoulder of application of force $P_{\mathrm{c}}$;

When radial force and cantilever load are necessary to minimize the maximum pressure (that calculated on IV theory of failure) $p_{\max }$ on the maximum amount $p_{\min (r)}$, which are derived from expressions(3) and (4), it is calculated in such way

$$
p_{\text {max }}=p_{\text {max }}^{\prime}-p_{\min (r)} \text {. }
$$

Maximum interference in which the shift of bush occurs regarding the shaft (disassembly of the shaft-bushing connection in field conditions) is determined by the formula

$$
N_{P \max }=\frac{Q \cdot L_{p} \cdot\left(C_{d} / E_{d}+C_{D} / E_{D}\right)}{f \cdot \pi \cdot l \cdot\left(r_{a} \cdot \operatorname{tg}(\alpha+)+0,67 \cdot f_{d} \cdot r_{s}\right)},
$$

where $Q$ - force on fixture arm, $\mathrm{N}$;

$L_{p}-$ load arm, m;

$C_{d}$ and $C_{D}$ - Lame coefficient of shaft and hole;

$E_{d}$ and $E_{D}$ - modules of elasticity of the material of the shaft and hole, $\mathrm{Pa}$;

$L$ - connection length, m;

$r_{\mathrm{a}}$ - average screw thread radius, $\mathrm{m}$;

$\alpha^{\prime}$ - lead angle of the screw thread;

$\varphi$ - reduced angle of friction in the threaded pair;

$F_{\mathrm{d}}$ - coefficient of friction at the end of the device;

$r_{\mathrm{s}}-$ support radius, $\mathrm{m}$.

Increased surface roughness leads to a decrease in the actual contact area [11], however, should limit the correction value for crushing surface roughness:

$$
\Delta N_{\mathrm{Rlim}} \leq 2 \cdot k_{\mathrm{R}} \cdot \eta \cdot\left(R_{\mathrm{adlim}}+R_{\mathrm{aDlim}}\right),
$$

where $k_{R}$ - conversion factor of surface roughness parameter $R_{a}$ to $R_{z}$;

$\eta$ - coefficient of crushing surface roughness;

$R_{a d \text { lim }}$ and $R_{a D \text { lim }}-$ maximum permissible parameters of the surface roughness at the shaft and hole (for most used parameters - from 18 to $120 \mathrm{~mm}$ : when pressing $R_{a d} \leq 1.25 \mu \mathrm{m}$ and $R_{a D} \leq 2.5 \mu \mathrm{m}$; when thermal expansion is recommended to increase by 2 times).

Recommendations of heat calculation details size in the fit in case of mating materials were developed. For the purpose of accounting of running according to the calculation of the smallest interference, it is proposed to introduce an impact factor of the fit [12]. For this case, when high rotation speed is lacking, dependence for the calculation of the limit technological interferences will be:

$$
\begin{gathered}
N_{T \max }=N_{P \max } \cdot \gamma+\Delta N_{R \pm} \Delta N_{t}, \\
N_{T \min =} N_{P \min } \cdot k+\Delta N_{R+} \Delta N_{d a} \pm \Delta N_{t},
\end{gathered}
$$

where $N_{T \max }-$ maximum technological interference, $\mu \mathrm{m}$;

$N_{T \min }-$ minimum technological interference, $\mu \mathrm{m}$;

$\Delta N_{R}$ - amendment, taking into account crushing the roughness of the hole and the shaft during the formation of the fit, $\mu \mathrm{m}$;

$\Delta N_{t}-$ amendment, taking account the thermal deformation of parts, $\mu \mathrm{m}$; 
$\Delta N_{d a}-$ amendment to reduce the interference during repeated disassembly-assemblies, $\mu \mathrm{m}$

$\gamma$-coefficient of increasing the specific pressure at the end of the hole;

$k-$ dynamic coefficient of the fit.

The calculation results are givenin the Table 2. Dissasembly-assembly conditions must be observed only for the connection at the sprocket with the shaft and the connection of the gear wheel with the shaft is installed in an enclosed reducer, which can be repaired only at specialized enterprises.

Correction of the obtained values of the interference was carried out with the use of amendmentsfor crushing of the surface roughness, for repeated disassembly, for the difference of temperature expansions of the parts forming the fit. For the greatest interference, a coefficient was introduced, in which the increase in the specific pressure at the ends of the sleeve was taken into account. The roughness of the surface of the hole and shaft $R_{a}=2.5 \mu \mathrm{m}$ normalized by the drawing in the "Mosselmash" gearbox being tested exceeds the allowable values to ensure a good contact area, for these sizes this value should be no more than $R_{a}=1.25 \mu \mathrm{m}$.

As a result of calculation it was found that for the compounds $\varnothing 30 \mathrm{~mm}$ sprocket (EN-GJL-200) with a steel shaft $(\mathrm{EN}-37 \mathrm{Cr} 4)$ and for the working temperature range from 0 to $60^{\circ} \mathrm{C}$, the correction for temperature expansion will have the $\Delta N_{t}$ range presented in Table 2. Cast iron expands more slowly than steel with increasing the temperature, there is an increase in interference, and, conversely, as the temperature decreases, steel decreases in size faster, interference decreases it. A positive $\Delta N_{t}$ value is substituted into the formula for determining the smallest technological interference $N_{T \min }(9)$, since it is necessary to compensate for the thermal reduction of interference (cooling). A negative value is substituted into the formula for determining $N_{T \max }(8)$, retaining the sign, since it is necessary to compensate for the thermal increase in interference (heating). For connection of steel gears (EN20Cr4) with a steel shaft (EN-37Cr4) correction for thermal deformation equals to zero.

Table 2

\section{Calculation of fits for connections of shaft with bush sprocket and shaft} with bush gear wheel for gearbox H090.20 "Mosselmash"

\begin{tabular}{|l|c|c|c|c|}
\hline \multicolumn{1}{|c|}{ Parameter } & \multirow{2}{*}{$\begin{array}{c}\text { Unit } \\
\text { measure }\end{array}$} & \multirow{2}{*}{$\begin{array}{c}\text { Descri- } \\
\text { ption }\end{array}$} & $\begin{array}{c}\text { Sprocket } \\
\text { coupling }\end{array}$ & $\begin{array}{c}\text { Gear } \\
\text { coupling }\end{array}$ \\
\hline Connection diameter & $\mathrm{m}$ & $\mathrm{d}_{\mathrm{n}}$ & $\varnothing 0.03$ & $\varnothing 0.04$ \\
\hline Shaft material - 37Cr4, hole material - & - & - & GJL-200 & $20 \mathrm{Cr} 4$ \\
\hline Connection length & $\mathrm{m}$ & $l$ & 0.058 & 0.035 \\
\hline Key width & $\mathrm{m}$ & $b$ & 0.012 & 0.012 \\
\hline $\begin{array}{l}\text { Allowable value for allowance of crushed } \\
\text { roughness }\end{array}$ & $\mu \mathrm{m}$ & $\Delta N_{R \text { lim }}$ & 11.25 & 11.25 \\
\hline Allowance on heat growth & $\mu \mathrm{m}$ & $\Delta N_{t}$ & $-1.6 \ldots 0.8$ & - \\
\hline $\begin{array}{l}\text { Maximum technological interference from } \\
\text { the conditions of disassembly - assembly }\end{array}$ & $\mu \mathrm{m}$ & $N_{T \max }$ & 78.31 & - \\
\hline $\begin{array}{l}\text { Maximum technological interference from } \\
\text { the conditions of thematerial strength }\end{array}$ & $\mu \mathrm{m}$ & $N_{T \max }$ & 124.74 & 151.24 \\
\hline $\begin{array}{l}\text { Minimum technological interferencefrom the } \\
\text { condition of torque transmission }\end{array}$ & $\mu \mathrm{m}$ & $N_{T \min (l)}$ & 36.88 & 26.17 \\
\hline $\begin{array}{l}\text { Minimum technological interference from the } \\
\text { condition of absence of joint opening in the } \\
\text { joint }\end{array}$ & $\mu \mathrm{m}$ & $N_{T \min (r)}$ & 14.95 & 12.15 \\
\hline $\begin{array}{l}\text { Standard fit from the condition of torque } \\
\text { transmission }\end{array}$ & - & - & - & $40 H 9 / z 8$ \\
\hline $\begin{array}{l}\text { Standard fit from the conditions of } \\
\text { disassembly - assembly }\end{array}$ & - & - & $30 H 7 / x 6$ & - \\
\hline
\end{tabular}

Analysis of the dynamics of wear of a connection with a serial and design fit showed that the rate of wear of the new connection of the sprocket with the shaft $\varnothing 30 H 7 / x 6$ is 12 times lower than the rate 
of wear of the serial $\varnothing 30 H 7 / h 9$. The wear rate of the new connection $\varnothing 40 H 9 / z 8$ is 3 times less than the wear rate of the serial $\varnothing 40 H 9 / n 6$. A significant reduction in the wear of the compounds under consideration was achieved due to a competent calculation of the fit accuracy parameters. In the presence of guaranteed interference in the fit there is no fretting and wear products are not formed.

\section{Conclusions}

1. For cylindrical connections with a key, which are widely used in agricultural engineering, a method of calculating the maximum and minimum interferences is used. The technique takes into account the need for disassembly and assembly work during operation, preventing the opening of the joint from the action of radial and cantilever load, as well as limited surface roughness of parts to form a stable contact area in the connection, influence of thermal expansion of parts on interference is analyzed.

2. For the universal reducer of the plant "Mosselmash" new fits for connection of the sprocket with the shaft $\varnothing 30 H 7 / x 6$ and connection of the gear with the shaft $\varnothing 40 H 9 / z 8$ were calculated and selected.

3. Due to a competent calculation of the fit accuracy parameters a significant reduction was achieved in the wear of the compounds under consideration. In the presence of guaranteed interference in the fit there is no fretting and wear products are not formed.

\section{References}

[1] Черноиванов В.И., Лачуга Ю.Ф., ЕжевскийА.А. Концепция модернизации инженернотехнической системы сельского хозяйства России на период до 2020 года (The concept of modernization of the engineering and technical system of agriculture in Russia for the period until 2020). Moscow: «Rosinformagrotech», 2010. 46 p. (In Russian).

[2] Пастухов А.Г. Повышение надежности карданных передач трансмиссий сельскохозяйственной техники (Increase of reliability of cardan gears of agricultural machinery transmissions). Thesis for a scientific degree of Doctor of Technical sciences. Moscow. 2008. 341 p. (In Russian).

[3] Пастухов А.Г. Оценка совершенства агрегатов механических трансмиссий (Assessment of the perfection of aggregates of mechanical transmissions). Tractors and agricultural machinery. Тракторы и сельскохозяйственные машины. 2008. № 4. pp. 40-44. (In Russian).

[4] Пастухов А.Г. Расчет экономического эффекта при повышении надежности агрегатов механических трансмиссий сельскохозяйственной техники (на примере карданных передач (Calculation of the economic effect with increasing reliability of aggregates of mechanical transmissions of agricultural machinery (using the example of cardan gears)). Vestnik MSAU. ВестникФГОУВПОМГАУ. 2008. № 2. pp. 152-153. (In Russian).

[5] Ерохин М.Н., Леонов О.А. Особенности обеспечения качества ремонта сельскохозяйственной техники на современном этапе (Features ensure the quality of repair of agricultural machinery at the present stage). Vestnik MSAU. ВестникФГОУВПОМГАУ. 2005. No.1. pp. 9-12. (In Russian).

[6] Repcic N., Saric. I., Muminovic A. Software for calculation and analysis of ISO system of tolerances, deviations and fits, International DAAM Symposium,2012, Volume 23, pp. 195-198.

[7] ISO 286-1:2010. Geometrical product specifications (GPS) - ISO code system for tolerances on linear sizes - Part 1: Basis of tolerances, deviations and fits.

[8] Ерохин М.Н. Детали машин и основы конструирования (Machine parts and design basics).Moscow. KolosS, 2005. 462 p. (In Russian).

[9] Boutoutaou H., Bouaziz M., Fontaine J.F. Modeling of interference fits taking form defects of the surfaces in contact into account, Materials \& Design, 2011, Volume 32, Issue 7, pp. 3692-3701.

[10] Seifi K., Abbasi K. Friction coefficient estimation in shaft/bush interference using finite element model updating, Engineering failure analysis, Department of Mechanical Engineering, Faculty of Engineering, Bu-Ali Sina University, Hamedan, 2015, Volume 57, pp. 310-322

[11] Seifi R., Abbasi K., Asayesh M. Effects of contact surface roughness of interference shaft/bush joints on its characteristics, Iranian journal of science and technology - transactions of mechanical engineering, Shiraz University, 2018,Volume 3, pp. 279-292. 
[12]Вергазова Ю.Г. Влияние точностных и технологических параметров на долговечность соединения «вал-втулка» (The influence of precision and technological parameters on the durability of the "shaft-bushing" connection). Vestnik MSAU. Вестник ФГОУВПОМГАУ. 2014. № 3. pp. 17-19. (In Russian). 